\title{
Amamentação e os desafios enfrentados pela mulher trabalhadora: um relato de experiência
}

\author{
Mateus Marcolin, Graziele Carolina de Almeida Marcolin, Alan Rodrigues de Souza, Amanda \\ Conrado Silva Barbosa, Lucélia Paula Gomes
}

\begin{abstract}
Resumo
Amamentar é o ato de alimentar o bebê com leite materno, advindo este diretamente da mama da puérpera. Nos últimos 10 anos acumularam-se evidências que fundamentaram a importância e eficácia da amamentação exclusiva (AME) nos primeiros 6 meses de vida da criança e demonstraram também que a alimentação complementar, utilizada de forma correta até os 2 anos ou mais, pode ser eficaz durante o desenvolvimento da criança. Os benefícios oferecidos pelo aleitamento materno são inúmeros, do ponto de vista biológico e social, pois esta prática traz vantagens para a mulher, para a criança, para a sua família e para a sociedade. Diante desse pressuposto, o objetivo do relato é identificar as principais dificuldades e desafios enfrentados pela mãe que amamenta quando há seu retorno ao trabalho após a licença maternidade. Dessa forma, a metodologia utilizada foi o relato de experiência, o qual ocorreu por meio de observação direta dos autores em meio a uma Unidade Básica de Saúde (UBS) no Município de Conselheiro Lafaiete MG. Os resultados demonstram que, a experiência como profissional de saúde em UBS, tem mostrado o conflito vivenciado pelas mães ao ter que conciliar a amamentação e o trabalho fora do lar. Ao aproximar o término da licença maternidade, nas várias oportunidades de atendimento oferecido ao binômio mãe/filho na unidade, as mães questionam a respeito de que alimentos oferecerem ao filho, como e quanto oferecê-los; como conservar o leite materno e quais os inconvenientes de se amamentar menos a criança; enfim como continuar a amamentar para que o filho não adoeça e cresça saudável. As mães vivenciam angústia, ansiedade, e ao mesmo tempo sentimento de culpa por deixar o filho aos cuidados de outra pessoa em detrimento do seu trabalho que, por sua vez, causam a interrupção da prática frequente da amamentação. Identificou-se que, mesmo que a mãe faça um plano de amamentação para o seu retorno ao trabalho e tenha conhecimentos sobre os benefícios da amamentação e conte com o apoio da família e dos profissionais de saúde, o retorno precoce ao trabalho, associado à falta de meios que favoreçam a manutenção da lactação como inflexibilidade do horário das mães, não contar com sala para extração e armazenamento do leite e creches dentro ou próximo ao local trabalho são fatores que influenciam negativamente a prática de amamentar. Os maiores vilões relacionados ao retorno da mãe ao trabalho são a extensa jornada de trabalho, a falta de incentivo e estrutura das empresas para a manutenção da lactação, além do cargo de responsabilidade que a mãe ocupa dentro da empresa e a importância que o trabalho tem na vida dessa mãe. Com isso, faz-se necessário um acolhimento das mães trabalhadoras a fim de se contribuir para a formação de novas e bem sucedidas nutrizes. Esse papel deve ser assumido pelos profissionais de saúde, de modo que haja mais informações que possam tranquilizar as mães a respeito das dificuldades reais que elas poderão encontrar em meio ao processo de amamentação durante seu retorno ao trabalho.
\end{abstract}

Descritores: Amamentação; Educação em Saúde; Trabalho. 